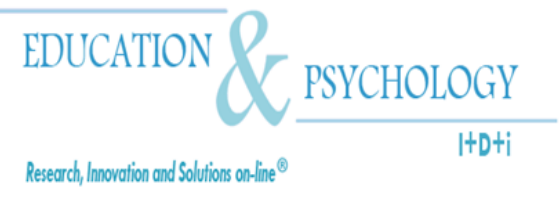

Electronic Journal of Research in Educational Psychology

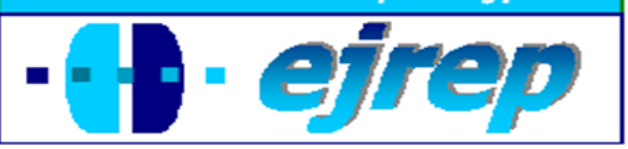

Editorial EOS

\title{
Turkish early childhood educators' sense of teacher efficacy
}

\author{
Huseyin Kotaman
}

School of Education, Ataturk University, Yoncalik, Erzurum

Turkey

Correspondence: Huseyin Kotaman. Kazim Karabekir School of Education, Ataturk University. Yoncalik, Erzurum. Turkey. E-mail: huskotaman@hotmail.com

(C) Education \& Psychology I+D+i and Editorial EOS (Spain) 


\begin{abstract}
Introduction. The current study explores the level of Turkish prospective and current early childhood teachers' sense of teacher efficacy.

Method. One hundred and six prospective, 243 early childhood teachers and a total of 389 participants were involved in the study. Participants responded to the Turkish version of Teacher Sense of Efficacy Scale (TTSES). TTSES also contains Student Engagement (SE), Instructional Strategies (IS) and Classroom Management (CM) subscales.
\end{abstract}

Results. Findings from the study revealed that participants obtained moderately high scores on SE, IS, CM subscales and whole sense of teacher efficacy. It was also found that practicing teachers have a significantly higher sense of teacher efficacy than prospective teachers.

Discussion and Conclusion. Findings revealed that Turkish earlychilhood prospective and experienced teachers have a moderately high sense of teacher efficacy. All experienced teachers receive significantly higher scores from teacher sense of efficacy scale than prospective teachers. This finding is consistent with the literature however steady increase in teacher efficacy with the years of teaching experience seems inconsistent with several studies. Therefore, conducing a teacher efficacy scale study which is specifically developed for early childhood educators, can provide better data.

Keywords: teacher efficacy, early childhood education, experienced and prospective Teachers, self-efficacy

Received: 12/08/09 Initial Acceptance: 12/09/09 Definitive Acceptance: 04/20/10 


\title{
Sentido de eficacia docente en los maestros turcos de educación infantil
}

\begin{abstract}
Resumen
Introducción. El presente estudio explora los niveles de sentimientos de eficacia docente entre profesorado de educación infantil en formación y en activo.

Método. Un total de 389 sujetos participan en el estudio, 106 profesores de educación infantil en formación y 243 profesores de educación infantil en activo. Los participantes respondieron a la versión turca de la Escala de Sentimiento de Eficacia Docente (ESED). La escala recoge subescalas que miden la implicación del alumnado (IA), estrategias de instrucción (EI) y gestión de aula (GA).
\end{abstract}

Resultados. Los resultados revelan que los participantes obtuvieron valores moderadamente altos en las escalas de IA, EI y GA así como en la valoración global del sentimiento de eficacia. También se observa que el profesorado en activo presenta un sentimiento de eficacia significativamente mayor que el profesorado en formación.

Discusión y Conclusiones. Los resultados apuntan que tanto el profesorado de educación infantil en activo, como el que está en formación, presentan niveles moderadamente altos en relación con el sentimiento de eficacia. El profesorado en activo presenta mayores puntuaciones que el profesorado en formación. El hallazgo es consistente con estudios previos aunque la estabilidad en el incremento de la eficacia docente con el paso de los años parece inconsistente en relación a otros estudios. Por consiguiente, la utilización de una escala de sentimiento de eficacia específicamente desarrollada para profesorado de educación infantil podría ofrecer mejores datos.

Palabras Clave: eficacia docente, educación infantil, profesorado en formación, profesorado en activo, autoeficacia.

Recibido: 08/12/09 Aceptación Inicial: 09/12/09 Aceptación Definitiva: 20/04/10 


\section{Introduction}

Bandura (1986, p. 391) defined self-efficacy as "People's judgments of their capabilities to organize and execute courses of action required to attain designated types of performance." Self-efficacy is a personal belief about the capacity to accomplish a certain task. It is important to have a realistic sense of self-efficacy because in terms of performance, selfefficacy beliefs work as initiators of behavior (Bandura, 1989) and also increase motivation and persistence (Bouffard-Bouchard, 1990; Multon, Brown, \& Lent, 1991). Self-efficacy mediates the effects of other self-beliefs and other variables, such as skill, ability and knowledge (Pajares \& Miller, 1994; Teti \& Gelfand, 1991). People with higher self-efficacy beliefs persist longer on a task when they face difficulties than people with lower self-efficacy beliefs. The stronger the belief in capabilities, the greater and more persistent are the efforts (Bouffard -Bouchard, 1990; Schunk, 1981; Zimmerman \& Ringle, 1981). People with higher selfefficacy belief attribute failure to insufficient effort or deficient knowledge and skills that are acquirable and quickly recover a sense of efficacy after failures or setbacks (Bandura, 1993).

According to Bandura (1989), there is a difference between possessing skills and being able to use them effectively and consistently under varied circumstances. Even though people have enough knowledge, skills and abilities to perform a certain task, they may have doubts about their skills and abilities. Therefore, they may not even attempt to perform the task. In order to perform a certain task, people should believe that their knowledge, skills and abilities are adequate to perform the task so they can attempt to perform it. If people are not fully convinced of their personal efficacy, they rapidly abandon the skills they have been taught. This is especially true when quick results fail to appear or bothersome effort is significant. They usually shy away from difficult tasks, and have low aspirations and weak commitment to the goals that they choose to pursue. In taxing situations, they dwell on their personal deficiencies, the formidableness of the task and adverse consequences of failure (Bandura, 1989).

Self-efficacy is an important predictor of performance and is a primary cause of feelings of self-worth and perceived usefulness. Self-efficacy beliefs are major mediators of behavior and behavior change. Accordingly, teacher efficacy is a specific case of self-efficacy (Bandura, 1997). Shaughnessy (2004) conducted an interview with Anita Woolfolk. In her interview she defined teacher efficacy as; “teachers' perceptions about their own capabilities 
to foster students' learning and engagement (p 154)." Just like self-efficacy teacher efficacy has direct impact on teachers and indirect impact on students through their teachers.

Teacher efficacy beliefs have been shown to predict students' motivation (Midgley, Feldlaufer, \& Eccles, 1989), and academic achievement (Bertsch, Houlihan, Lenz, \& Patte, 2009; Goddard, Hoy, \& Hoy 2000; Muijs \& Reynold, 2002; Shidler, 2009). That is students with more efficacious teachers perform better academically and expected to do better in the future than their peers who have teachers with a low sense of teacher efficacy. The study of Muijs and Reynold (2002) is especially important because they found that teacher selfefficacy related to students achievement even when it is controlled for prior achievement and background factors. They also found that efficacious teachers are more open to innovations more willing to work on their professional and personal improvement than less efficacious teachers. Teacher efficacy has an impact on teachers' use of teaching strategies. Efficacious teachers are more willing to implement new instructional ideas (Gaith \& Yaghi, 1997) and they are better at promoting learning of slow students than less efficacious teachers (Shachar \& Shmuelevitz, 1997). It has been found that a high sense of teacher efficacy relates to less interventionist and more democratic classroom management (Gencer \& Cakiroglu, 2007). Teacher efficacy belief also relates to teachers' professional commitment (Ware \& Kitsantas, 2007; Ross, A. J. \& Bruce, C. 2007), professional skills (Lavella, 2006) job satisfaction in teaching, experiencing less stress during teaching (Tschannen-Moran, Hoy \& Hoy, 1998) and teacher burnout (Skaalvik \& Skaalvik, 2007).

These studies revealed the importance of a sense of teacher efficacy for the performance of teachers and their students. Therefore, it is important to determine teachers' level of teacher efficacy belief. Measuring teacher beliefs of efficacy make it possible to determine deficiencies in teachers' sense of teacher efficacy. Thus programs can be developed to support and increase teachers' self-efficacy beliefs.

In Turkey only a few studies have been conducted on teacher efficacy issues. Gencer and Cakiroglu (2005) investigated pre-service science teachers' sense of teacher efficacy and its' relationship with classroom management. Yenice (2009) compared the levels of science teachers' sense of teacher efficacy according to several characteristis of teachers such as gender, seniority, weekly lesson load and receiving inservice training. Çapa, Çakıroğlu and Sarıkaya (2005), adapted the Teacher Sense of Efficacy Scale (TSES) of Tschannen-Moran 
and Woolfolk (1998) to Turkish. Participants of Çapa, Çakıroğlu and Sarıkaya (2005) were senior students who majored in prospective mathematics education (14\%), elementary science education $(21 \%)$, early childhood education (15\%), and classroom teaching program $(51 \%)$. Albeit, there have been no studies conducted just with Turkish or some other countries early childhood education prospective and current teachers on teacher sense of efficacy beliefs to the author's knowledge. Consequently, this study is of great importance, because of its originality and relevance. The purpose of this study is to determine the levels of teacher efficacy beliefs on instructional strategies, classroom management, student engagement and a global sense of teacher efficacy of Turkish pre-service and in-service early childhood teachers. Since the mastery experiences are the most effective sources of self-efficacy (Bandura, 1977, 1986) this study also investigates differences among teacher efficacy beliefs according to their levels of teaching experience.

\section{Method}

\section{Participants}

This study's population included prospective early childhood education teachers from two major universities in Ankara, one university in Erzurum and current early childhood education teachers from Ankara, Istanbul, Bursa, Trabzon and Erzurum in Turkey. One hundred and forty six recent graduate preschool teachers partcipated from two universities in Ankara and one university in Erzurum. Two hundred and forty three preschool teachers from 26 different schools in five major cities (Istanbul, Ankara, Bursa, Erzurum and Trabzon) of four regions around Turkey responded to the Teachers' Sense of Efficacy Scale (TTSES). Three hundred and ninety teachers were asked to respond to the scale only one of them refused to respond stating: "These questions are not related to early childhood education." A total of 389 participants took part in the study. Of the 146 prospective teachers, 16 were male $(11 \%)$ and 130 were female $(89 \%)$. The ages of the prospective teachers ranged from 20 to 26 , with a mean age of $22.8(\mathrm{SD}=1.2)$. Of the 243 teachers four were male $(1.6 \%)$ and 239 were female (98.4\%). The ages of teachers ranged from 22 to 55, with a mean age of $30.5(\mathrm{SD}=7.4)$. Of the 243 teachers 121 had 1 to 5 years of teaching experience (49\%), 59 had 6-11 years of teaching experience (24\%), 39 had 12-17 years of teaching experience (16\%) and 24 had 17 and more than 17 years of teaching experience (10\%). 


\section{Instrument}

Participants responded to the Turkish version of Teacher Sense of Efficacy Scale (TTSES). The TTSES is a reliable and valid instrument that measures general sense of teacher efficacy containing 24 items (Çapa, Çakıroğlu, and Sarıkaya, 2005) and has three subscale measures: Efficacy for Instructional Strategies, Efficacy for Classroom Management, Efficacy for Student Engagement. Çapa, Çakıroğlu and Sarıkaya (2005) conducted a study to adapt the scale and Turkish. From six different universities 628 preservice teachers participated to their study. They found coefficient alpha values of 0.82 for SE, 0.86 for IS, and 0.84 for CM. For the whole scale, they found 0.93 as the reliability of efficacy scores. Thus they reached high reliability scores. Investigators conducted confirmatory factor analysis to determine validity of the scale. Their findings yielded 0.99 TLI and CFI, which indicated perfect fit of the oblique three-factor model to the efficacy data. Also, RMSEA of about 0.5 indicated a close fit of the model. These findings yielded that the TTSES with its' three subscales is a reliable and valid instrument that measures general sense of teacher efficacy containing 24 items.

Cronbach alpha coefficient determined the reliability of the efficacy scores. An analysis of the study revealed reliability scores of $0.89,0.90,0.90,0.96$ for SE, IS, CM and whole scale respectively. These Cronbach's coefficients are considered to indicate sound reliability (Isaac \& Michael, 1995).

\section{Procedure and Design}

The study utilized survey design. Investigator visited the schools and universities and distributed Turkish form of Teachers' Sense of Efficacy Scale by himself. Participants individually responded to the scale in their own time. Investigator conducted a second visit to the schools and universities to gather responded TTSES. Investigator keypunched data by himself. The data analysis procedures were conducted and completed using a statistical package for the social sciences for Windows. 


\section{Results}

Average scores were calculated to determine the participants' global sense of efficacy and efficacy for student engagement, instructional strategies and classroom management. On average participants had an efficacy score of 7.71, 7.8, 7.75, on a nine point scale Student Engagement (SE), Instructional Strategies (IS), and Classroom Management (CM) subscales respectively. Also the average for global Teacher Sense of Efficacy (TSE) was 7.75 on a ninepoint scale.

Participants are grouped according to their teaching experiences. Of the 389 participants 72 prospective teachers had no formal teaching experience and 121 teachers had 1 to 5 years, 59 teachers had 6-11 years, 39 teachers had 12-17 years and 24 teachers had 18 and more than 18 years of teaching experience respectively. Investigator used experience distribution because the mastery experiences are the most effective sources of self-efficacy (Bandura, 1977, 1986) therefore the study investigates differences among teacher efficacy beliefs according to their levels of teaching experience. Anova compares the mean scores of three subscales and the whole scale of prospective teachers and the four groups of experienced teachers.

Table 1. ANOVA for SE Efficacy

\begin{tabular}{lrrcccc}
\hline Teaching Experiences & \multicolumn{1}{c}{ N } & Means & Std. Deviations & F & Df & Sig. \\
\hline 0 years & 146 & 7.33 & 1 & & & \\
1-5 years & 121 & 7.84 & 0.77 & & & \\
6-11 years & 59 & 7.92 & 0.72 & 12.49 & 4 & $<0.001$ \\
12-17 year & 39 & 8.15 & 0.70 & & & \\
18-above & 24 & 8.1 & 0.79 & & & \\
\hline
\end{tabular}

Table 1 presents the ANOVA scores for the Student Engagement subscale. Mean scores for SE were 7.33, 7.84, 7.92, 8.15 and 8.1 with SD of $1,0.77,0.72,0.70$, and 0.79 from least experienced to most experienced respectively. ANOVA revealed a statistically significant difference among the groups mean score $[\mathrm{F}(4,389)=12.5, \mathrm{p}<.01]$. The Scheffe post hoc analysis results indicate significant differences among the prospective teachers and the rest of the participants. Significant differences were found at the .05 level. However, no significant differences were found among experienced teachers. 
Table 2 presents the ANOVA scores for the Instructional Strategies subscale. Mean scores for IS were 7.48, 7.88, 7.94, 8.15, 8.16 with SD of $1,0.78,0.80,0.76$, and 0.86 from least experienced to most experienced respectively. ANOVA revealed a statistically significant difference among the groups mean score $[\mathrm{F}(4,389)=7.55, \mathrm{p}<.01]$. The Scheffe post hoc analysis results indicate significant differences among the prospective teachers and the rest of the participants. Significant differences were found at the .05 level. However, no significant differences were found among experienced teachers.

Table 2. ANOVA for IS Efficacy

\begin{tabular}{lrrcccc}
\hline Teaching Experience & \multicolumn{1}{c}{ N } & Means & Std. Deviations & F & Df & Sig. \\
\hline 0 years & 146 & 7.48 & 1 & & & \\
1-5 years & 121 & 7.88 & 0.78 & & & \\
6-11 years & 59 & 7.94 & 0.80 & 7.55 & 4 & $<0.001$ \\
12-17 year & 39 & 8.15 & 0.76 & & & \\
18-above & 24 & 8.16 & 0.86 & & & \\
\hline
\end{tabular}

Table 3 presents the ANOVA scores for the Classroom Management subscale. Mean scores for $\mathrm{CM}$ were $7.35,7.91,7.94,8.01,8.16$ and 8.13 with SD of 1.1, 0.74, 0.77, 0.72, and 0.84 from least experienced to most experienced respectively. ANOVA revealed a statistically significant difference among the groups mean score $[\mathrm{F}(4,389)=12.69, \mathrm{p}<.01]$. The Scheffe post hoc analysis results indicate significant differences among the prospective teachers and the rest of the participants. Significant differences were found at the 0.05 level. However, no significant differences were found among experienced teachers.

Table 3. ANOVA for CM Efficacy

\begin{tabular}{lrrcccc}
\hline Teaching Experience & \multicolumn{1}{c}{ N } & Means & Std. Deviations & F & Df & Sig. \\
\hline 0 years & 146 & 7.35 & 1.1 & & & \\
1-5 years & 121 & 7.91 & 0.74 & & & \\
6-11 years & 59 & 8.01 & 0.77 & 12.69 & 4 & $<0.001$ \\
12-17 year & 39 & 8.16 & 0.72 & & & \\
18-above & 24 & 8.13 & 0.84 & & & \\
\hline
\end{tabular}

Mean scores for whole scale were 7.39, 7.89, 7.95, 8.15, 8.12 with SD of 0.97, 0.71, $0.72,0.68$, and 0.82 from least experienced to most experience respectively. ANOVA revealed a statistically significant difference among the group mean score $[\mathrm{F}(4,389)=12.12$, $\mathrm{p}<.01]$. The Scheffe post hoc analysis results indicate significant differences among the pro- 
spective teachers and the rest of participants. Significant differences were found at the .05 level. However, no significant differences were found among experienced teachers.

Table 4. ANOVA for Whole Scale Efficacy

\begin{tabular}{lrrcccc}
\hline Teaching Experience & \multicolumn{1}{c}{$\mathbf{N}$} & Means & Std. Deviations & F & Df & Sig. \\
\hline 0 years & 146 & 7.39 & 0.97 & & & \\
1-5 years & 121 & 7.88 & 0.71 & & & \\
6-11 years & 59 & 7.96 & 0.72 & 12.12 & 4 & $<0.001$ \\
12-17 year & 39 & 8.15 & 0.68 & & & \\
18-above & 24 & 8.13 & 0.82 & & & \\
\hline
\end{tabular}

\section{Discussion}

Results showed that prospective and current early childhood teachers in Turkey have a moderately high sense of teacher efficacy. The participants mean scores for all three subscales and whole scale were above 7 in some cases above 8 out of 9 , which indicates a moderately high sense of teacher efficacy. These averages are slightly above the averages that were found by Çapa, Çakıroğlu and Sarıkaya (2005) and Çakıroğlu, Çakıroğlu, and Boone (2005). In their study Çapa, Çakıroğlu and Sarıkaya (2005) used the Turkish teachers' sense of efficacy scale and measured the sense of teacher efficacy of several prospective teachers. They found an average of 6.92 for SE, 7.10 IS, and 6.95 CM. Çakıroğlu, Çakıroğlu, and Boone (2005) measured personal science teaching efficacy beliefs (PSTE) and science teaching outcome expectancy of preservice elementary (STOE). They found an average of 4.25 for PSTE and 4.37 for STOE out of 6 . This small difference is understandable when we consider that this study employed prospective teachers as well as current teachers who have mastery experiences which are considered to be the most effective source of self-efficacy belief (Bandura, 1977, 1986).

Also, the averages of prospective early childhood education teachers' were slightly higher than the averages of participants of Çapa, Çakıroğlu and Sarıkaya (2005) and Çakıroğlu, Çakıroğlu, and Boone (2005). This difference can be explained by the nature of early childhood classroom atmosphere and applications. In Turkey there are apparent differences in classroom environment and applications between early childhood education and elementary and higher school education. The early childhood classroom environments and applications are less formal and more flexible than elementary school and higher education. There- 
fore it can be expected that early childhood teachers feel more control over their job, which in return may cause the increase in teacher efficacy belief (Goddard, Hoy, \& Hoy, 2004).

ANOVA results revealed that there were significant differences for teacher efficacy scores from Student Engagement, Instructional Strategies, Classroom Management subscales and whole scale scores between prospective teachers and experienced teachers in favor of experienced teachers. However, there were no significant differences among experienced teachers in terms of SE, IS, CM subscale scores and whole scale scores. Teachers who had teaching experience between 11-17 years obtained the highest mean scores from the SE and CM subscale and from the whole scale. In the Instructional Strategies subscale teachers with 18 or more years of teaching experiences obtained the highest mean score. In all subscales and in the whole scale teachers who had 11 years or more teaching experience reached higher mean scores than teachers with less teaching experience and prospective teachers. This steady increase in teacher efficacy with the years of teaching experience appear consistent with Bandura's (1977) self-efficacy theory in that he states mastery experiences as the most effective source of self-efficacy belief. Notwithstanding, several studies such as Wagler (2005) and Hoy, and Spero (2005) revealed a decrease in teacher efficacy belief in the early years of teaching. This inconsistency can be sourced from the measurement device that was used in this study. Bandura (1986) emphasized the importance of the specificity of self-efficacy assessment and correspondence to criterial tasks. According to Bandura, self-efficacy must be specifically rather than globally assessed because self-efficacy beliefs are domain- and taskspecific. The TTSES contains items that are related to and more appropriate for elementary school and higher education such as the items for IS: "To what extent can you use a variety of assessment strategies?"; CM "How much can you do to control disruptive behavior in the classroom?"; and for SE "How much can you do to get students to believe they can do well in schoolwork?" Therefore, conducting a teacher efficacy scale study which is specifically developed for early childhood educators, can provide better data.

Findings reveal that Turkish prospective and current early childhood education teachers have moderately high levels of teacher efficacy belief on Student Engagement, Instructional Strategies, Classroom Management and general teacher efficacy. Bandura stated that, "If self-efficacy beliefs always reflected only what people can do routinely, people would rarely fail, but neither would they mount the extra effort needed to surpass their ordinary performance" (Bandura, 1989, p. 421). Therefore, having an optimistic sense of teacher efficacy 
might increase teachers' motivation and persistence against difficulties. However findings also indicated no decrease in the sense of teacher efficacy during the first years of teaching as it is encountered in the literature. On the contrary a steady increase was found in the sense of teacher efficacy. Therefore, the investigator questions how realistically prospective and current early childhood teachers evaluate their sense of teacher efficacy. Unrealistic evaluation of teacher efficacy may cause disappointment when the prospective teachers begin teaching or when teachers are faced with failure (Bandura, 1997). Further studies that investigate the predictive power of early childhood teachers' teacher sense of efficacy on different aspects such as teachers' motivation, professional commitment, students' motivation and academic achievement should be conducted in Turkey. Thus, it would be possible to find out how realistic early childhood teachers are when they are evaluating the level of their sense of teacher efficacy.

\section{References}

Bandura, A. (1977). Self-efficacy: Toward a unifying theory of behavioral change. Psychological Review, 84, 191-215.

Bandura, A. (1986). Social foundations of thought and action: A social cognitive theory (1th ed.). New Jersey: Prentice-Hall, Inc.

Bandura, A. (1989). Human agency in social cognitive theory. American Psychology, 44, $1175-1184$.

Bandura, A. (1993). Perceived self-efficacy in cognitive development and functioning. $E d u$ cational Psychologist, 28, 117-148.

Bandura, A. (1997). Self-efficacy: The exercise of control. New York: Freeman.

Bertsch, K., Houlihan, D., Lenz, M., \& Patte, C. (2009). Teachers' commands and their role in preschool classrooms. Electronic Journal of Research in Educational Psychology, 17, 7(1), 133-162.

Bouffard-Bouchard, T. (1990). Influence of self-efficacy on performance in a cognitive task. The Journal of Social Psychology, 130, 353-363.

Çapa, Y., Çakıroğlu, J. \& Sarıkaya, H. (2005). The development and validation of a Turkish version of teachers' sense of efficacy scale. Ĕ̈itim ve Bilim, 30, 74-81.

Çakıroğlu, J., Çakıroğlu, E., \& Boone, J. W. (2005). Pre-service teacher self-efficacy beliefs regarding science teaching: A comparison of pre-service teachers in Turkey and the USA. Science Educator, 14, 31-40. 
Gencer, S. A., \& Cakiroglu, J. (2007). Turkish preservice science teacher' efficacy beliefs regarding science teaching and their beliefs about classroom management. Teaching and Teacher Education, 23, 664-675.

Ghaith, G., \& Yaghi, H. (1997). Relationship among experience, teacher efficacy, and attitudes toward the implementation of instructional innovation. Teaching and Teacher Education, 13, 451-458.

Goddard, D. R., Hoy K. W., \& Hoy W. A. (2000). Collective teacher efficacy: Its meaning, measure, and impact on student achievement. American Educational Research Journal, 37, 479-507.

Goddard, D. R., Hoy K. W., \& Hoy, W. A. (2004). Theoretical developments, empirical evidence, and future directions. Educational Research, 33, 3-13.

Hoy, W. A., \& Spedo, B. R. (2005). Changes in teacher efficacy during the early years of teaching: A comparison of four measures. Teaching and Teacher Education, 21, 343356.

Isaac, S., \& Michael, W. (1995). Handbook in research and evaluation: a collection of principles, methods, and strategies useful in the planning, design, and evaluation of studies in education and the behavioral sciences. San Diego: EdITS Publisher.

Lavella, E. (2006). Teachers' self-efficacy for writing. Electronic Journal of Research in Educational Psychology, 4(1), 73-84.

Midgley, C., Feldlaufer, H., \& Eccles, S. J. (1989). Change in teacher efficacy and student self- and task-related beliefs in mathematics during the transition to junior high school. Journal of Educational Psychology, 81, 247-258.

Muijs, D. \& Reynolds, D. (2002). Teacher beliefs and behaviors: What really matters? Journal of Classroom Interaction, 37, 1-15.

Multon, D. K., Brown, D. S., \& Lent, W. R. (1991). Relation of self-efficacy beliefs to academic outcomes: A meta-analytic investigation. Journal of Counseling Psychology, $38,30-38$.

Pajares, F., \& Miller, M. D. (1994). Role of self-efficacy and self-concept beliefs in mathematical problem solving: A path analysis. Journal of Educational Psychology, 86, 193-203.

Ross, A. J. \& Bruce, C. (2007). Professional development effects on teacher efficacy: Results of randomized flied trial. The Journal of Educational Research, 101, 50-60. 
Shachar, H. \& Shmuelevitz, H. (1997). Implementing cooperative learning, teacher collaboration and teachers' sense of efficacy in heterogeneous junior high schools. Contemporary Educational Psychology, 22, 53-72

Shaughnessy, M. (2004). An interview with Anita Woolfolk: The educational psychology of teacher efficacy. Educational Psychology Review, 16, 152-176.

Shidler, L. (2009). The impact of time spent coaching for teacher efficacy on student achievement. Early Childhood Education Journal, 36, 453-460.

Schunk, D. H. (1981). Modeling and attributional effects on children's achievement: A selfefficacy analysis. Journal of Educational Psychology, 73, 93-105.

Skaalvik, M. E., \& Skaalvik, S. (2007). Dimensions of teacher self-efficacy and relations with strain factors, perceived collective teacher efficacy, and teacher burnout. Journal of Educational Psychology, 99, 611-625.

Teti, M. D., \& Gelfand, M. D. (1991). Behavioral competence among mothers of infants in the first year: The mediational role of maternal self-efficacy. Child Development, 62, 918-929.

Tschannen-Moran, Hoy, A. W., \& Hoy, K. W. (1998). Teacher efficacy: Its meaning and measure. Review of Educational Research, 68, 202-248.

Yenice, N. (2009). Search of science teachers' teacher efficacy and self-efficacy levels relating to science teaching for some variables. Procedia Social and Behavioral Sciences, $1,1062-1067$.

Wagler, R. (2005). Preservice teacher efficacy; effects of a secondary education methods course and student teaching. Teacher education \& practice; the journal of the Texas Association of Colleges for Teacher Education, 18, 442-457.

Ware, H. \& Kitsantas, A. (2007). Teacher and collective efficacy beliefs as predictors of professional commitment. The Journal of Educational Research, 100, 303-310.

Zimmerman, J. B., \& Ringle, J. (1981). Effects of model persistence and statements of confidence on children's self-efficacy and problem solving. Journal of Educational Psychology, 73, 485-493. 